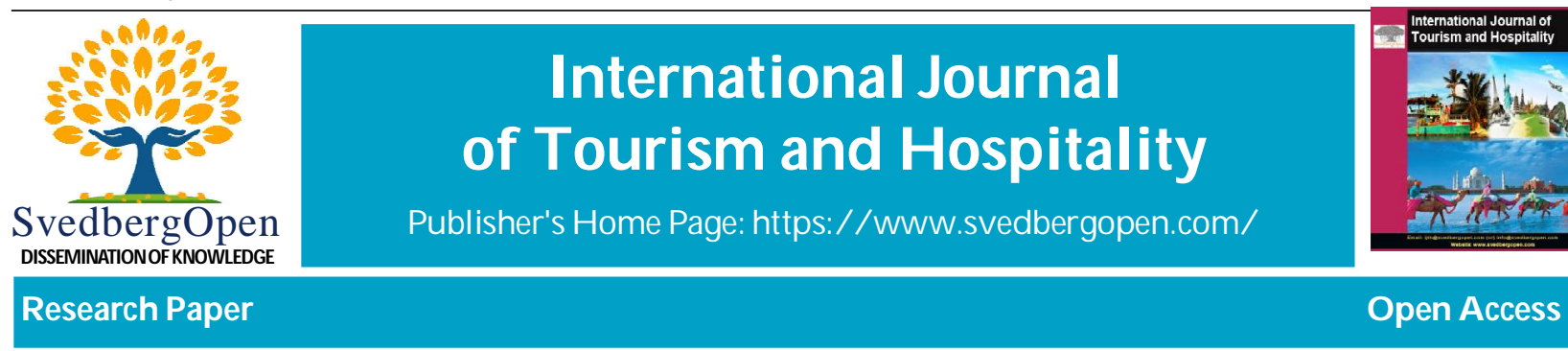

\title{
Public Transportation Issues and Challenges During the Pandemic
}

Canet, Lena N. ${ }^{1 *}$, Adriano, Jessica P. ${ }^{2}$, Buensuceso, Abner, G. ${ }^{3}$, Dela Cruz, Maybelle N. ${ }^{4}$, Pulumbarit, Catherine B. ${ }^{5}$ and Hilario, Nino Angelo, D. ${ }^{6}$

${ }^{1}$ Bulacan State University, Malolos, Bulacan, Philippines. Email: lena.canet@bulsu.edu.ph

${ }^{2}$ Bulacan State University, Malolos, Bulacan, Philippines. Email: jessica.adriano@bulsu.edu.ph

${ }^{3}$ Bulacan State University, Malolos, Bulacan, Philippines. Email: abner.buensuceso@bulsu.edu.ph

${ }^{4}$ Bulacan State University, Malolos, Bulacan, Philippines. Email: maybelle.delacruz@bulsu.edu.ph

${ }^{5}$ Bulacan State University, Malolos, Bulacan, Philippines. Email: catherine.pulumbarit@bulsu.edu.ph

${ }^{6}$ Bulacan State University, Malolos, Bulacan, Philippines. Email: ninoangelo.hilaro@bulsu.edu.ph

\section{Article Info}

Volume 1, Special Issue 1, December 2021 Received : 11 August 2021

Accepted : 19 November 2021

Published : 05 December 2021

https://doi.org/10.51483/IJTH.1.S1.2021.S44-S55

\begin{abstract}
During the pandemic, no one was allowed to go outside except those front liners because of lockdown to avoid Covid-19 transmission. Many people become unemployed, particularly public transportation drivers. All public transit in Bulacan has been suspended. Drivers and commuters also were affected. As a result, the researchers wanted to know how the pandemic impacts commuters and drivers, particularly in the province of Bulacan. The purpose of this study is to integrate the experiences of public transportation prevention and control techniques with the prevention and regulation of public transportation travel in Bulacan, which is one of the most important variables in the economic and cultural recovery of Bulacan and globally.

Keywords: Pandemic, Transportation, Covid-19, Lockdown, Bulacan, Philippines

(C) 2021 Canet, Lena N. et al. This is an open access article under the CC BY license (https://creativecommons.org/licenses/by/4.0/), which permits unrestricted use, distribution, and reproduction in any medium, provided you give appropriate credit to the original author(s) and the source, provide a link to the Creative Commons license, and indicate if changes were made.
\end{abstract}

\section{Introduction}

The coronavirus infection, often known as (Covid-19), has lately spread rapidly over the world. For many people, public transportation is their primary method of transportation, and in other cases, their only mode of transportation. Because of the pandemic's global spread, effective long-term preventative and control measures for at-risk populations during the Pandemic should be established, as well as a cure. Covid- 19 has affected approximately 200 countries and locations, according to the World Health Organization (2020), with more than 19.46 million confirmed cases as of August 9th, 2020.

Public transportation is a type of locally offered travel that allows individuals to travel together along specific routes. Individuals can travel together along particular routes using public transportation, which is a sort of locally supplied travel. Buses, jeepneys, tricycles, and taxis are examples of public transportation in Bulacan. According to Schwartz (2020), public transportation has a number of characteristics that are linked to a higher Covid-19 score. Transmission risk, which includes the possibility of overcrowding on buses, jeepneys, and other forms of transit.

\footnotetext{
* Corresponding author: Canet, Lena N ., Bulacan State U niversity, M alolos, Bulacan, Philippines. E mail: lena.can et@bulsu.edu.ph
} 
Because of Covid-19, many people are affected by this kind of situation. During the pandemic, no one was allowed to go outside except those frontliners because of lockdown to avoid Covid-19 transmission. Many people are jobless, especially those drivers of public transport. All public transportation in Bulacan has stopped its operation. Commuters and drivers are affected. According to Ugay (2020), in the labor force, most Filipinos are commuters.

As a reason, the researchers sought to determine how the pandemic affects commuters and drivers particularly in the Province of Bulacan. The goal of this research is to combine the experience of public transportation prevention and control methods with the prevention and regulation of public transportation travel in Bulacan, which is one of the most significant factors in the economic and cultural recovery of Bulacan and also globally. During a pandemic, like as the Covid-19, public transportation is one of the most impacted because the government establishes the protocol that we must follow for our own security. The closure of all companies and institutions, as well as lockdowns and other health precautions, resulted in a decrease in public transit.

\section{Methodology}

To evaluate the issues and challenges of public transportation amid the pandemic, this study utilized both qualitative and quantitative methods. Random sample procedures were used to collect data in order to address and explain the study questions under investigation. Tricycle drivers, Jeepney drivers, and passengers in the municipality of Hagonoy Bulacan made up the study's respondents.

The researchers created and validated a self-constructed questionnaire that consisted of three (3) parts: Part I includes the demographic profiles of the respondents: (a) age, (b) gender, (c) civil status, and (d) years of service as a public transportation driver. Part II discusses how the public transportation business changed during the pandemic in terms of (a) passenger numbers, (b) routes, (c) fare prices, (d) availability, and (e) new governmental rules.

Part III discusses the issues and challenges that the public transportation industry faced during the pandemic.

The collected data was organized using a hybrid technique and represented through survey forms/questionnaires and interviews. The relevant responses from surveys and interviews were entered into a data matrix with appropriate codes, and computerization was used. The mean, frequency, and percentage were used to determine the potential issues and challenges that commuters and drivers who drive public vehicles/public transportation may encounter following the pandemic.

\section{Results}

Table 1 reveals that 20 or $40 \%$ of responders are passengers, 15 or $30 \%$ are tricycle drivers, and 15 or $30 \%$ are jeepney drivers, for a total of 50 or $100 \%$. Random sampling was used to choose the respondents.

Table 1: Frequency and Percentage Distribution of Respondents According to Drivers and Passengers

\begin{tabular}{|l|c|c|}
\hline Drivers and Passengers & Frequency & Percentage \\
\hline Passengers & 20 & $40 \%$ \\
\hline Tricycle Drivers & 15 & $30 \%$ \\
\hline Jeepney Drivers & 15 & $30 \%$ \\
\hline Total & $\mathbf{5 0}$ & $\mathbf{1 0 0 \%}$ \\
\hline
\end{tabular}

Table 2 illustrates the age of passengers: 3 or $15 \%$ are under the age of 20,12 or $60 \%$ are between the ages of 21 and 35,3 or $15 \%$ are between the ages of 36 and 50, and 2 or $10 \%$ are 52 and over. The data shows that the majority of the travelers are between the ages of 21 and 35. They are employees who were allowed to leave the house during the pandemic because they were exempted from lockdown.

Table 3 indicates the genders of passengers, with 6 males accounting for $30 \%$ of the total and 14 females accounting for $70 \%$. The table shows that the majority of the passengers are female. Despite the fact that it is pandemic, females are more likely to commute or use public transportation than males. Despite the fact that women are represented as house mainstays, Shirkant (2019) claims that women have typically traveled more than men. 
Table 2: Age of Passengers

\begin{tabular}{|l|c|c|}
\hline Age & Frequency & Percentage \\
\hline Below 20 & 3 & $15 \%$ \\
\hline $21-35$ & 12 & $60 \%$ \\
\hline $36-50$ & 3 & $15 \%$ \\
\hline 51 yrs and above & 2 & $10 \%$ \\
\hline Total & $\mathbf{2 0}$ & $\mathbf{1 0 0 \%}$ \\
\hline
\end{tabular}

\begin{tabular}{|l|c|c|}
\hline \multicolumn{2}{|l|}{ Table 3: Gender of Passengers } \\
\hline Gender & Frequency & Percentage \\
\hline Male & 6 & $30 \%$ \\
\hline Female & 14 & $70 \%$ \\
\hline Total & $\mathbf{2 0}$ & $\mathbf{1 0 0 \%}$ \\
\hline
\end{tabular}

Table 4 illustrates the civil status of passengers, with $14(70 \%)$ of them being single and $6(30 \%)$ of them being married. The data shows that the majority of the travelers are single. Single individuals travel more frequently than married people. The researchers discover that the majority of single passengers are employed and rely on public transportation to get to work.

\begin{tabular}{|l|c|c|}
\hline \multicolumn{2}{|l|}{ Table 4: Civil Status of Passengers } \\
\hline Civil Status & Frequency & Percentage \\
\hline Single & 14 & $30 \%$ \\
\hline Married & 6 & $0 \%$ \\
\hline Separated & 0 & $0 \%$ \\
\hline Others & 0 & $\mathbf{1 0 0 \%}$ \\
\hline Total & $\mathbf{2 0}$ & \multirow{2}{*}{$0 \%$} \\
\hline
\end{tabular}

The Table 5 illustrates the number of years' passengers have been commuting: 1 or $5 \%$ have been commuting for less than one year, 2 or $10 \%$ have been commuting for one to five years, 4 or $20 \%$ have been traveling for six to ten years, and 13 or $65 \%$ have been commuting for 11 years or more. The data shows that the majority of passengers have been utilizing public transit for many years. So, even though it's a pandemic, they're taking public transportation to their preferred location. Staying at home is the safest approach to protect yourself and others against Covid-19. However, some people must leave their homes to go to work, food shop, or perform important errands.

Table 6 indicates how many passengers were permitted during the pandemic. 8 or $40 \%$ of them are below 2,5 or $25 \%$ are 2-3 passengers, 1 or $5 \%$ of them are $4-5$ and 6 or $30 \%$ of them are 6-10.

The data shows that the majority of them have restricted capacity or less than two people on public transit in order to avoid the transmission of Covid-19 and maintain social distance from one another. All kinds of public transportation should adhere to the one-meter physical distance rules. 
Table 5: Number of Years in Commuting

\begin{tabular}{|l|c|c|}
\hline Numbers of Years in Commuting & Frequency & Percentage \\
\hline Below 1 year & 1 & $5 \%$ \\
\hline $1-5$ years & 2 & $20 \%$ \\
\hline $6-10$ years & 4 & $65 \%$ \\
\hline 11 years and above & 13 & $\mathbf{1 0 0 \%}$ \\
\hline Total & $\mathbf{2 0}$ & \\
\hline
\end{tabular}

Table 6: Number of Passengers per Vehicle During the Pandemic

\begin{tabular}{|l|c|c|}
\hline How Many Were Allowed Passengers During the Pandemic & Frequency & Passenger \\
\hline Below 2 & 8 & $25 \%$ \\
\hline $2-3$ & 5 & $5 \%$ \\
\hline $4-5$ & 1 & $30 \%$ \\
\hline $6-10$ & $\mathbf{2 0}$ & $\mathbf{1 0 0 \%}$ \\
\hline Total & 6 & $25 \%$ \\
\hline
\end{tabular}

Table 7 indicates how many passengers responded yes or no to the question of whether the normal route changed during the pandemic, with yes accounting for $14 \%$ and no accounting for just $6 \%$. The data shows that during the pandemic, the majority of travelers deviate from their usual route.

Table 7: Route During the Pandemic

\begin{tabular}{|c|c|c|}
\hline Did the Normal Route Change During the Pandemic? & Frequency & Percentage \\
\hline Yes & 14 & $70 \%$ \\
\hline No & 6 & $\mathbf{1 0 0 \%}$ \\
\hline Total & $\mathbf{2 0}$ \\
\hline
\end{tabular}

The Table 8 shows the how much is fare before pandemic. Passengers who replied below 10 Php were 3 or $15 \%, 11$ $20 \mathrm{Php}$ is 12 or $60 \%, 21-30 \mathrm{Php}$ is 3 or $15 \%$, and $31 \mathrm{Php}$ and above is just 2 or $10 \%$. According to the data, before to the Pandemic, the majority of travelers paid a standard rate of 11-20 PHP.

\begin{tabular}{|c|c|c|}
\hline \multicolumn{2}{|l|}{ Table 8: Fare Before Pandemic } \\
\hline How Much is Fare Before Pandemic? & Frequency & Percentage \\
\hline Below 10 Php & 3 & $60 \%$ \\
\hline $11-20 \mathrm{Php}$ & 12 & $15 \%$ \\
\hline $21-30 \mathrm{Php}$ & 3 & $10 \%$ \\
\hline $31 \mathrm{Php}$ and above & 2 & $\mathbf{1 0 0 \%}$ \\
\hline Total & $\mathbf{2 0}$ & \\
\hline
\end{tabular}


Table 9 indicates how much fare is charged during a pandemic. The passengers who responded that 11-20 Php is 6 or 30\%, 21-30 Php is 9 or 45\%, and $31 \mathrm{Php}$ and higher is only 5 or $25 \%$. The table shows that during the pandemic, there was a significant increase in the fare.

Table 9: Fare During the Pandemic

\begin{tabular}{|l|c|c|}
\hline How Much is the Fare During the Pandemic? & Frequency & Percentage \\
\hline Below 10 Php & 0 & $0 \%$ \\
\hline $11-20 \mathrm{Php}$ & 6 & $30 \%$ \\
\hline $21-30 \mathrm{Php}$ & 9 & $25 \%$ \\
\hline 31 Php and above & $\mathbf{2 0}$ & $\mathbf{1 0 0 \%}$ \\
\hline Total & & $55 \%$ \\
\hline
\end{tabular}

Table 10 depicts if there was enough public transportation available throughout the pandemic. The number of passengers who replied yes is just $4(20 \%)$, whereas the number of passengers who said no is $16(80 \%)$. It is shown that the public transportation during the pandemic is not enough due to government restrictions and policies on lockdowns and health protocols.

Table 10: Availability of Transportation During Pandemic

\begin{tabular}{|c|c|c|}
\hline Is There Enough Public Transportation During the Pandemic & Frequency & Percentage \\
\hline Yes & 4 & $20 \%$ \\
\hline No & 16 & $80 \%$ \\
\hline Total & $\mathbf{2 0}$ & $\mathbf{1 0 0 \%}$ \\
\hline
\end{tabular}

Table 11demonstrates what government policies during the pandemic change your normal trip. The number of passengers who answered lockdown is 9 or $45 \%$, social distancing is 10 or $50 \%$ and others is only 1 or $5 \%$. It was discovered that the policy of social distancing had a significant impact on the normal trip during the epidemic.

Table 11: Government Policies that has Affected the Normal Trip During Pandemic

\begin{tabular}{|c|c|c|}
\hline What Government Policies During the Pandemic Change Your Normal Trip? & Frequency & Percentage \\
\hline Lockdown & 9 & $45 \%$ \\
\hline Social Distancing & 10 & $50 \%$ \\
\hline Curfew & 0 & $0 \%$ \\
\hline Other & 1 & $5 \%$ \\
\hline Total & $\mathbf{2 0}$ & $\mathbf{1 0 0 \%}$ \\
\hline
\end{tabular}

Table 12 demonstrates that just one tricycle driver, or $6.67 \%$, is under the age of 20 and another, or $6.67 \%$, is between the ages of 21 and 35. There were 6 people between the ages of 36 and 50, or 40\%, and 7 people between the ages of 51 and 100 , or $46.67 \%$. The table shows that drivers aged 51 and up account for the biggest percentage of the total number of drivers. Because riding a tricycle is their sole source of income, and it is also their major occupation even until they reach old age. 
Table 12: Age of Tricycle Drivers

\begin{tabular}{|l|c|c|}
\hline Age & Frequency & Percentage \\
\hline Below 20 years old & 1 & $6.67 \%$ \\
\hline $21-35$ years old & 1 & $6.67 \%$ \\
\hline $36-50$ years old & 6 & $40 \%$ \\
\hline 51 years old and above & 7 & $46.67 \%$ \\
\hline Total & $\mathbf{1 5}$ & $\mathbf{1 0 0 \%}$ \\
\hline
\end{tabular}

The gender of tricycle drivers is seen in Table 13, with 15 or $100 \%$ of the respondents being male. All of the tricycle drivers are male, as seen in the table, because in this area, men are the ones who work while their wives stay at home.

Table 13: Gender of Tricycle Drivers

\begin{tabular}{|c|c|c|}
\hline Gender & Frequency & Percentage \\
\hline Male & 15 & $100 \%$ \\
\hline Female & 0 & $0 \%$ \\
\hline Total & $\mathbf{1 5}$ & $\mathbf{1 0 0 \%}$ \\
\hline
\end{tabular}

Table 14 reveals that 1 respondent $(6.67 \%)$ is single, 12 respondents (80\%) are married, and 2 respondents $(13.33 \%)$ is separated. The table shows that the majority of the people is married and need to work every day to support their families.

\begin{tabular}{|l|c|c|}
\hline \multicolumn{2}{|l|}{ Table 14: Civil Status of Tricycle Drivers } \\
\hline Civil Status & Frequency & Percentage \\
\hline Single & 1 & $6.67 \%$ \\
\hline Married & 12 & $80 \%$ \\
\hline Separated & 2 & $13.33 \%$ \\
\hline Others & 0 & $0 \%$ \\
\hline Total & $\mathbf{1 5}$ & $\mathbf{1 0 0 \%}$ \\
\hline
\end{tabular}

Table 15 displays the number of years they have worked as a public transportation driver. 4 or $26.67 \%$ of tricycle public transportation drivers have been in service for 1 to 5 years, 1 or $6.67 \%$ have been in service for 6 to 10 years, and

\begin{tabular}{|c|c|c|}
\hline \multicolumn{2}{|l|}{ Table 15: Years in Service } & Frequency \\
\hline Years in Service as Public Transport Driver & 0 & $0 \%$ \\
\hline Below 1 year & 4 & $26.67 \%$ \\
\hline $1-5$ years & 1 & $6.67 \%$ \\
\hline $6-10$ years & 10 & $66.67 \%$ \\
\hline 11 years and above & $\mathbf{1 5}$ & $\mathbf{1 0 0 \%}$ \\
\hline Total & & \\
\hline
\end{tabular}


10 or $66.67 \%$ have been in service for 11 years or more. The data shows that the majority of tricycle drivers have been doing so for a long period. Their profession as a tricycle driver allows them to support their families.

Table 16 illustrates the number of people who were permitted to ride in the tricycle during the epidemic. Out of 15 respondents, $11(73.33 \%)$ said that the maximum number of passengers allowed on a tricycle is less than two, while only $4(26.67 \%)$ said that two to three passengers are allowed. According to the table, most tricycles are authorized to operate in the region if they have just two or less passengers as they must adhere to government protocol, which is social distancing.

Table 16: Number of Passengers per Tricycle During the Pandemic

\begin{tabular}{|c|c|c|}
\hline How Many Were The Allowed Passengers During The Pandemic & Frequency & Percentage \\
\hline Below 2 & 11 & $73.33 \%$ \\
\hline $2-3$ & 4 & $26.67 \%$ \\
\hline $4-5$ & 0 & $0 \%$ \\
\hline $6-10$ & 0 & $0 \%$ \\
\hline Total & $\mathbf{1 5}$ & $\mathbf{1 0 0 \%}$ \\
\hline
\end{tabular}

This is seen in Table 17. When asked if their path during the epidemic had altered, $9 \%$ replied yes and $6 \%$ said no. Because to lockdowns in certain locations and impassable roads due to checkpoints, the typical itinerary was altered during the pandemic.

Table 17: Tricycle Route during the Pandemic

\begin{tabular}{|c|c|c|}
\hline Did the Normal Route Change During The Pandemic & Frequency & Percentage \\
\hline Yes & 9 & $60 \%$ \\
\hline No & 6 & $40 \%$ \\
\hline Total & $\mathbf{1 5}$ & $\mathbf{1 0 0 \%}$ \\
\hline
\end{tabular}

Table 18 reveals that, of the 15 respondents, 6 or $40 \%$ said the fare before the pandemic was less than 10 php, 8 or $53.33 \%$ said it was $11-20 \mathrm{php}$, and 1 or $6.67 \%$ said it was $21-30 \mathrm{php}$. Prior to the pandemic, the typical tricycle fare was between 11 and $20 \mathrm{Php}$.

Table 18: Fare Before Pandemic

\begin{tabular}{|c|c|c|}
\hline How Much is the Fare Before the Pandemic & Frequency & Percentage \\
\hline Below 10 & 6 & $40 \%$ \\
\hline $11-20$ & 8 & $53.33 \%$ \\
\hline $21-30$ & 0 & $6.67 \%$ \\
\hline 31 and above & $\mathbf{1 5}$ & $0 \%$ \\
\hline Total & $\mathbf{1 0 0 \%}$ \\
\hline
\end{tabular}

According to Table 19, out of 15 respondents, 2 or $13.33 \%$ indicated the fare is less than $20 \mathrm{php}, 2$ or $13.33 \%$ answered $11-20 \mathrm{php}, 1$ or $6.67 \%$ said $21-30 \mathrm{php}$, and 10 or $66.67 \%$ said $31 \mathrm{php}$ and beyond. The data shows that the tricycle fare has increased significantly. 
Table 19: Fare During the Pandemic

\begin{tabular}{|c|c|c|}
\hline How Much was the Fare During Pandemic? & Frequency & Percentage \\
\hline Below 10 php & 2 & $13.33 \%$ \\
\hline $11-20 \mathrm{php}$ & 2 & $13.33 \%$ \\
\hline $21-30 \mathrm{php}$ & 10 & $6.67 \%$ \\
\hline $31 \mathrm{php}$ and above & $\mathbf{1 5}$ & $66.67 \%$ \\
\hline Total & $\mathbf{1 0 0 \%}$ \\
\hline
\end{tabular}

According to Table 20, 4 or $26.67 \%$ of respondents said that all members of their association are permitted to travel, whereas 11 or $73.33 \%$ said no. According to the data, the majority of tricycle drivers are unable to go for public transit due to pandemic restrictions.

Table 20: Restrictions on Travel

\begin{tabular}{|c|c|c|}
\hline $\begin{array}{c}\text { Are All Your Members Allowed to Travel for Public Transportation } \\
\text { Purposes During the Pandemic? }\end{array}$ & Frequency & Percentage \\
\hline Yes & 4 & $26.67 \%$ \\
\hline No & 11 & $73.33 \%$ \\
\hline Total & $\mathbf{1 5}$ & $\mathbf{1 0 0 \%}$ \\
\hline
\end{tabular}

According to Table 20, 4 or $26.67 \%$ of respondents answered that all members of their association are allowed to travel, whereas 11 or $73.33 \%$ responded no. According to the research, due to pandemic restrictions, the majority of tricycle drivers are unable to go out for trip.

Table 21: Government Policies that has Affected the Normal Trip during Pandemic

\begin{tabular}{|c|c|c|}
\hline What governmental policies during the pandemic changed your normal trip? & Frequency & Percentage \\
\hline Lockdown & 10 & $66.67 \%$ \\
\hline Social Distancing & 3 & $20 \%$ \\
\hline Curfew & 2 & $13.33 \%$ \\
\hline Others & 0 & 0 \\
\hline Total & $\mathbf{1 5}$ & $\mathbf{1 0 0 \%}$ \\
\hline
\end{tabular}

Table 21 presents the government policies that has affected the normal trip during pandemic. It shows that $66.67 \%$ answered lockdown to be the government policy that affected the normal trip during pandemic, $20 \%$ answered social distancing, and $13.23 \%$ answered curfew.

Table 22 displays the average age of jeepney drivers. 2 or $13.33 \%$ are between the ages of 21 and 35,7 or $46.67 \%$ are between the ages of 36 and 50, and 6 or $40 \%$ are 51 and older. The table shows that the majority of responders are between the ages of 36 and 50 .

The gender of jeepney drivers is seen in Table 23. Males account for around 15\% of the population. It is clear that all of the answers are from males. This illustrates that men outnumber women as drivers. Female drivers are quite rare.

Table 24 indicates the respondents' civil status. 2 (or 13.33\%) of the 15 respondents are single, while 13 (or $86.67 \%$ ) are married. According to the data, the majority of responders are married and have families to support. 
Table 22: Age of Jeepney Drivers

\begin{tabular}{|l|c|c|}
\hline Age & Frequency & Percentage \\
\hline Below 20 & 0 & 0 \\
\hline $21-35$ years & 2 & $13.33 \%$ \\
\hline $36-50$ years & 7 & $46.67 \%$ \\
\hline 50 years \& above & 6 & $40 \%$ \\
\hline Total & $\mathbf{1 5}$ & $\mathbf{1 0 0 \%}$ \\
\hline
\end{tabular}

Table 23: Gender of Jeepney Drivers

\begin{tabular}{|l|c|c|}
\hline Gender & Frequency & Percentage \\
\hline Male & 15 & $100 \%$ \\
\hline Female & 0 & $\mathbf{1 0 0 \%}$ \\
\hline Total & $\mathbf{1 5}$ & 0 \\
\hline
\end{tabular}

\begin{tabular}{|l|c|c|}
\hline \multicolumn{2}{|l|}{ Table 24: Civil Status of Jeepney Drivers } \\
\hline Civil Status & Frequency & Percentage \\
\hline Single & 2 & $86.33 \%$ \\
\hline Married & 13 & 0 \\
\hline Separated & 0 & 0 \\
\hline Others & 0 & $\mathbf{1 0 0 \%}$ \\
\hline Total & $\mathbf{1 5}$ & \multirow{2}{*}{0} \\
\hline
\end{tabular}

Table 25 indicates the number of years of experience as a public transportation driver. 0 or none of the respondents stated that they have less than one year of service, 2 or $13.33 \%$ have 1 to 5 years of service, 6 or $40 \%$ have 6 to 10 years of service, and 7 or $46.67 \%$ have 11 years of service. The data shows that the majority of the drivers have above 11 years of experience, since many of them choose to work as a driver at a young age.

Table 25: Years in Service

\begin{tabular}{|l|c|c|}
\hline Years in service as Public Transport driver's & Frequency & Percentage \\
\hline Below 1 year & 0 & $0 \%$ \\
\hline $1-5$ years & 2 & $13.33 \%$ \\
\hline $6-10$ years & 6 & $40 \%$ \\
\hline 11 years above & 7 & $46.67 \%$ \\
\hline Total & $\mathbf{1 5}$ & $\mathbf{1 0 0 \%}$ \\
\hline
\end{tabular}


Table 26 indicates how many travelers were permitted throughout the pandemic. 0 or none of the respondents claimed that less than 2, 2-3, and 4-5 people are enough to fill a single jeepney, while 15 or $100 \%$ of the respondents said that 6-10 passengers are sufficient to allow inside the jeepney before they travel.

Table 26: Number of Passengers per Jeepney during the Pandemic

\begin{tabular}{|c|c|c|}
\hline How many were allowed passengers during the pandemic? & Frequency & Percentage \\
\hline Below 2 & 0 & $0 \%$ \\
\hline $2-3$ & 0 & $0 \%$ \\
\hline $4-5$ & 0 & $100 \%$ \\
\hline $6-10$ & 15 & $\mathbf{1 0 0 \%}$ \\
\hline Total & $\mathbf{1 5}$ & $0 \%$ \\
\hline
\end{tabular}

Table 27 demonstrates whether the normal route changed during the pandemic. 60\% (40\%) of those surveyed replied yes, while sixty percent $(60 \%)$ said no. According to the data, the majority of respondents said no if their usual route changed during a pandemic. During the pandemic, the jeepney drivers' association did not change their normal route. As a result of the lockdowns, they have been completely shut down for several months.

Table 27: Jeepney Route during the Pandemic

\begin{tabular}{|c|c|c|}
\hline Did normal route change during the pandemic? & Frequency & Percentage \\
\hline Yes & 6 & $40 \%$ \\
\hline No & 9 & $60 \%$ \\
\hline Total & $\mathbf{1 5}$ & $\mathbf{1 0 0 \%}$ \\
\hline
\end{tabular}

Table 28 illustrates how much the fare is before the pandemic. 0 or none of the respondents said the fare is less than 10 pesos, 10 or $66.67 \%$ said the fare is $11-20$ pesos, 5 or $33.33 \%$ said the fare is $21-30$ pesos, and 0 or none of the respondents said the fare is 31 pesos or more. According to the data, the majority of drivers claimed that the fare per passenger is 11-20 pesos. The drivers and passengers are aware that the minimum fare in a jeepney is 11-20 pesos.

Table 28: Fare before the Pandemic

\begin{tabular}{|c|c|c|}
\hline How much is the fare before pandemic? & Frequency & Percentage \\
\hline Below 10 & 0 & $0 \%$ \\
\hline $11-20$ & 10 & $66.67 \%$ \\
\hline $21-30$ & 5 & $33.33 \%$ \\
\hline 31 and above & 0 & $0 \%$ \\
\hline Total & $\mathbf{1 5}$ & $\mathbf{1 0 0 \%}$ \\
\hline
\end{tabular}

Table 29 illustrates how much the fare was during the pandemic. 0 or none of the respondents stated the fare was less than 10 pesos, 2 or $13.33 \%$ said the fare was $11-20$ pesos, 12 or $80 \%$ said the fare was $21-30$ pesos per person, and 1 or $6.67 \%$ said the fare was 31 pesos or more. According to the statistics, there has been an increase in the fare during the pandemic since the capacity of the jeepney has been reduced, requiring them to charge double in order to cover their expenses such as fuel, boundary, and even maintenance. 
Table 29: Fare During the Pandemic

\begin{tabular}{|c|c|c|}
\hline How much was the fare during pandemic? & Frequency & Percentage \\
\hline Below 10 & 0 & $0 \%$ \\
\hline $11-20$ & 2 & $13.33 \%$ \\
\hline $21-30$ & 12 & $60 \%$ \\
\hline 31 and above & 1 & $6.67 \%$ \\
\hline Total & $\mathbf{1 5}$ & $\mathbf{1 0 0 \%}$ \\
\hline
\end{tabular}

According to the data, most drivers were not permitted to travel for public transit purposes during the pandemic due to governmental measures implemented during lockdowns.

Table 30: Restrictions on Travel

\begin{tabular}{|c|c|c|}
\hline $\begin{array}{c}\text { Are all your members allowed to travel for Public Transportation } \\
\text { purposes during the pandemic? }\end{array}$ & Frequency & Percentage \\
\hline Yes & 5 & $33.33 \%$ \\
\hline No & 10 & $66.67 \%$ \\
\hline Total & $\mathbf{1 5}$ & $\mathbf{1 0 0 \%}$ \\
\hline
\end{tabular}

Table 31 indicates how government measures during the pandemic affected normal jeepney movement, and 5 or $33.33 \%$ of respondents answered lockdown, 9 or $60 \%$ said social distancing, 1 or $6.67 \%$ said curfew, and 0 or none mentioned others.

Table 31: Government Policies that has Affected the Normal Trip during the Pandemic

\begin{tabular}{|c|c|c|}
\hline What governmental policies during the pandemic changed your normal trip? & Frequency & Percentage \\
\hline Lockdown & 5 & $33.33 \%$ \\
\hline Social Distancing & 9 & $60 \%$ \\
\hline Curfew & 1 & $6.67 \%$ \\
\hline Others & 0 & $0 \%$ \\
\hline Total & $\mathbf{1 5}$ & $\mathbf{1 0 0 \%}$ \\
\hline
\end{tabular}

\section{Discussion}

Based on the data gathered, the researchers found that the majority of persons who used public transit are between the ages of 21 and 35, which is the most suitable age for going outdoors during lockdowns.

The recommended distance to ensure public safety is a heavily debated subject, with various governments and health groups offering a variety of distancing recommendations. Most nations and the World Health Organization suggest a 1.5- to 2-meter social separation. As a result, the fare during the pandemic has increased. Because of government regulations, the passenger capacity of public transportation has been restricted.

Due to checkpoints and the closure of various barangays, the route has modified. 
The majority of jeepney and tricycle drivers had changed employment, and some had temporarily quit since their wages were insufficient to meet their demands.

\section{Conclusion}

The intensive changes in public transportation, as well as the overview of efforts aimed at preventing viral transmission, provide extraordinary challenges to the public transportation industry. Furthermore, these variations require an excessive pause, and the shifting characteristics of the pandemic do not always follow a consistent recovery route. To deal with these quick and dramatic changes, public transportation companies had to rely on limited information. Following a thorough study of the data, it is recommended that public transportation scheduling be addressed at the strategic level. It relates to the design of a public transportation link, which includes identifying public transportation terminals and expanding public transportation routes. To alleviate the strain on public transportation drivers, a franchise tax exemption be adopted within the jurisdiction of Hagonoy Bulacan.

In addition, for terminals with a high volume of public transit, reducing service frequencies is strongly advised. Changes in vehicle schedules and a reduction in the overall time of daily operations should also be considered.

\section{References}

Schwartz, S. (2020). Public Transit a Safe Way to Travel During the COVID-19 Pandemic. available at https://www.apta.com/ research-technical-resources/research-reports/public-transit-and-covid-19-pandemic-global-research-and-bestpractices/

Shirkant, A. (2019). Women Travel Alone More Than Men. Here's Why. available at https://www.vox.com/the-goods/ 2019/1/18/18188581/women-travel-alone-men

Ugay, J. (2020). Terminal: The Constant Agony of Commuting Amid the Pandemic. available at https://www.rappler.com/ nation/photo-essay-agony-daily-commuting-metro-manila-covid-19-pandemic

World Health Organization. (2020). Coronavirus Cause: Origin and How it Spreads. available at https:// www.medicalnewstoday.com/articles/coronavirus-causes

Cite this article as: Canet, Lena N., Adriano, Jessica P., Buensuceso, Abner, G., Dela Cruz, Maybelle N., Pulumbarit, Catherine B. and Hilario, Nino Angelo, D. (2021). Public Transportation Issues and Challenges During the Pandemic. International Journal of Tourism and Hospitality. 1(S1), S44-S55. https://doi.org/10.51483/IJTH.1.S1.2021.S44-S55. 